\title{
Selected properties of Vanadis 8 tool steel after grinding and hard turning
}

\author{
Wybrane właściwości stali narzędziowej Vanadis 8 \\ po szlifowaniu oraz toczeniu na twardo
}

\section{DANIEL TOBOKA JOLANTA CYBOROŃ \\ ANETA ŁĘTOCHA*}

Two mechanical processes of surface layer (SL) modification were performed on Vanadis 8 tool steel: grinding $(G)$ and hard turning (HT). This steel is classified as powder metallurgy (P/M) high-alloyed tool steel. Heat treatment was carried out in vacuum furnaces with gas quenching until hardness of 64 \pm 1 HRC was achieved. Surface geometrical structures (SGS), microstructures, residual stress levels and wear resistance of SL resulting in these processes were compared.

KEYWORDS: tool steel, grinding, hard turning, surface geometrical structure, microstructure

Przeprowadzono dwa mechaniczne procesy modyfikacji warstwy wierzchniej (WW) stali narzędziowej Vanadis 8: szlifowanie oraz toczenie na twardo. Stal ta klasyfikowana jest jako wysokostopowa stal narzędziowa otrzymywana technologia metalurgii proszków (P/M). Obróbkę cieplną przeprowadzono w piecu próżniowym z hartowaniem w gazie aż do uzyskania twardości $64 \pm 1$ HRC. Porównano struktury geometryczne powierzchni, mikrostrukturę, poziom naprężeń szczątkowych oraz zużycie ścierne WW uzyskane w wyniku tych procesów. SŁOWA KLUCZOWE: stal narzędziowa, szlifowanie, toczenie na twardo, struktura geometryczna powierzchni, mikrostruktura

The deterioration of the performance of tools for cold forming generally takes place as a result of progressive tribological wear during operation. Dramatic consequences of wear have been discussed in textbooks $[1,2]$. Preparation of a durable tool for cold working processes consists of a thermal treatment, shaping and machining for a dimensional accuracy and forming the surface layer (SL) of determined quality (high smoothness, sufficient hardness, etc.) [3]. In traditional manufacturing processes, the finishing operation of tools and machine parts is often grinding. Thus, hardness after heat treatment higher than $45 \mathrm{HRC}$ and sometimes even $60 \mathrm{HRC}$ can be achieved. For several decades in many industries, e.g. automotive, bearing, molds and dies manufacturing, processes of grinding are gradually replaced by so called "hard machining" (HM) [4]. In order to achieve SL of workpieces with an appropriate set of attributes - so called surface integrity - which have a positive influence on the

* Dr inż. Daniel Toboła (daniel.tobola@ios.krakow.pl), mgr inż. Jolanta Cyboroń (jolanta.cyboron@ios.krakow.pl), mgr inż. Aneta Łętocha (aneta.letocha@ios.krakow.pl) - Instytut Zaawansowanych Technologii Wytwarzania
DOI: https://doi.org/10.17814/mechanik.2017.10.129

performance characteristics of products (eg. tools), we performed the above mentioned mechanical processes on modern P/M Vanadis 8 tool steel.

\section{Experimental}

The chemical composition of P/M tool steel under trade name of "Vanadis ${ }^{\circledR} 8$ SuperClean" from Uddeholm Company is given in Table I.

The specimens $(\varnothing 32 \times 20 \mathrm{~mm})$ were machined and

TABLE I. Chemical composition of Vanadis 8 steel (wt. \%).

\begin{tabular}{|c|c|c|c|c|c|c|}
\hline Element & $\mathrm{C}$ & $\mathrm{Si}$ & $\mathrm{Mn}$ & $\mathrm{Cr}$ & $\mathrm{Mo}$ & $\mathrm{V}$ \\
\hline Vanadis 8 & 2.3 & 0.4 & 0.4 & 4.8 & 3.6 & 8.0 \\
\hline
\end{tabular}

subjected to a heat treatment (austenizing temperature $1190^{\circ} \mathrm{C}$, soaked $4 \mathrm{~min} 30 \mathrm{~s}$; third tempering for $2 \mathrm{~h}$ at $530^{\circ} \mathrm{C}$ ) in vacuum furnaces with gas quenching until hardness of $64 \pm 1$ HRC was achieved. After the heat treatment, two types of mechanical processes were performed (see Fig. 1).

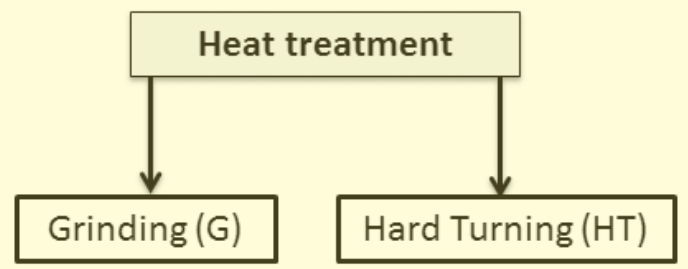

Fig. 1. Scheme of two types of carried out surface treatments

Front face grinding with $\mathrm{cBN}$ (cubic boron nitride) wheels with resinous bond was carried out on universal tool grinder 3E642 type, at the following parameters: peripheral speed of the wheel $v_{\mathrm{s}}=16 \mathrm{~m} / \mathrm{s}$; table feed speed $v_{\mathrm{f}}=210 \mathrm{~mm} / \mathrm{min}$; working engagement $a_{\mathrm{e}}=0.01 \mathrm{~mm}$.

Mori Seiki NL2000SY turning-milling CNC center, equipped with fixing system described in earlier work [5], was used for hard turning on samples end faces.

Hard turning applying PCBN (polycrystalline cubic boron nitride) cutting inserts with commercial names NP-DCGW11T302GA2 BC020 was performed at the following conditions: cutting speed $v_{\mathrm{c}}=150 \mathrm{~m} / \mathrm{min}$, feed $f=0.02 \mathrm{~mm} / \mathrm{rev}$. and cutting depth $a_{\mathrm{p}}=0.1 \mathrm{~mm}$. 
3D surface roughness parameters were measured using a laboratory profilometer TOPO 01, developed at Institute of Manufacturing Technology (IAMT). It was equipped with a $1 \mathrm{~mm}$ measuring head, diamond tip with a radius of $2 \mu \mathrm{m}$ and a cone angle of $90^{\circ}$. Data analysis and surface topography were developed in Mountain Map v.7 by Digital Surf.

Microstructures of SL after selected treatments were determined using a JEOL JSM $6460 \mathrm{~V}$ digital scanning electron microscope equipped with an energy dispersive X-ray spectrometer (EDS).

The X-ray diffraction (XRD) measurements were performed with a PANalytical Empyrean diffractometer using copper radiation $(\lambda \mathrm{Cu}=1.5406 \AA)$. The phase analyses were performed using the ICDD PDF-4+ 2016 files.

Stress measurements were carried out on the aforementioned diffractometer using a 5-axis table, for two directions defined by the angle $\varphi: 0^{\circ}$ and $90^{\circ}$ as shown in Fig. 2. The most common $\sin ^{2} \psi$ method for $X$-ray stress determination was used.

In the present studies, the residual stress calculations were performed by considering the $\alpha$-Fe (211) line: $2 \theta=$ $=82.17^{\circ}, \mathrm{dhkl}=1.1721 \AA$. The Young modulus $E=211$ $\mathrm{GPa}$ and the Poisson ratio $v=0.2882$ were used.
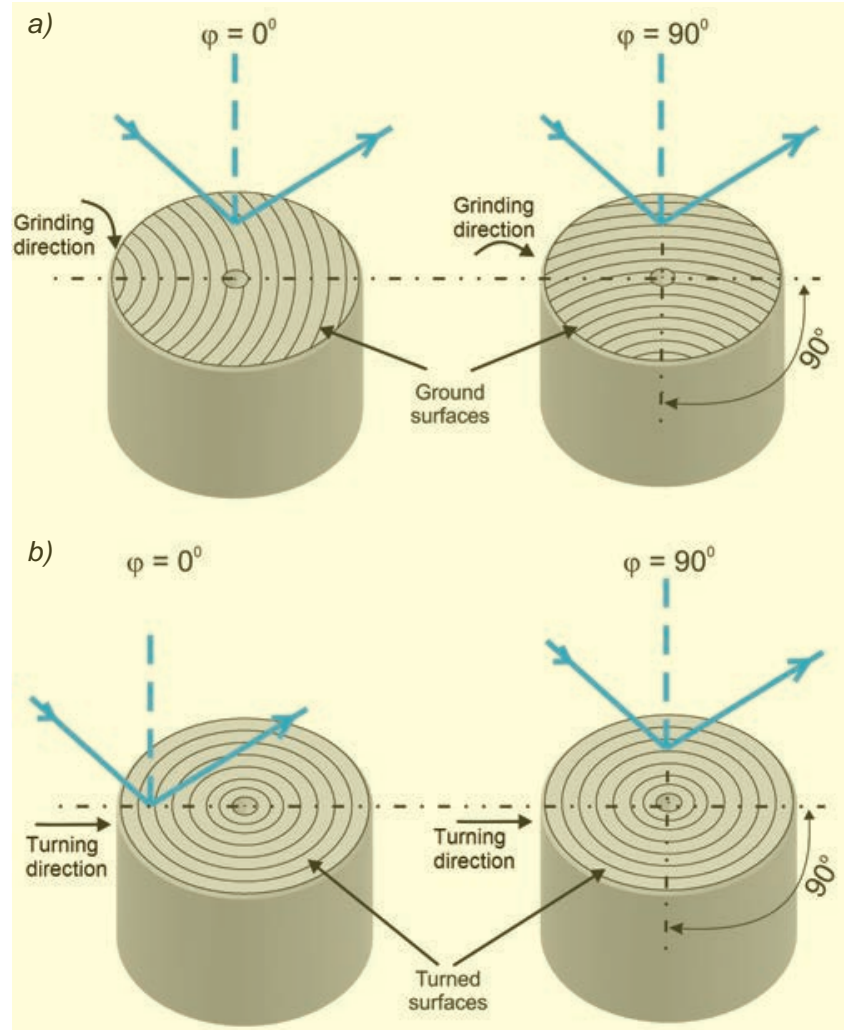

Fig. 2. Orientations of samples regarding to direction of primary $\mathrm{X}$-ray beam and type of surface treatment: a) grinding, $b$ ) hard turning

The abrasive wear resistance was evaluated by wellknown pin-on-disc method [2]. More information about the mechanical tester and how the measurements were conducted have been provided earlier [6]. The tests were carried out without a lubricant at room temperature, under maximum Hertzian contact pressure not exceeding 1800 $\mathrm{MPa}$. The following test conditions were applied: $\mathrm{Al}_{2} \mathrm{O}_{3}$ ball diameter $=10.0 \mathrm{~mm}$, applied load $=25.0 \mathrm{~N}$, sliding speed $=0.1 \mathrm{~m} / \mathrm{s}$, diameter of the sliding circle $=7.0 \mathrm{~mm}$, sliding distance $=2500 \mathrm{~m}$, calculated duration of the test $2 \cdot 10^{4} \mathrm{~s}$. Dynamic friction $\mu$ and wear rate Ws were calculated by well-known standard formulas also reported in [6].

\section{Results}

Figure 3 shows both a typical microstructure as well as XRD patterns for quenched and tempered Vanadis 8 steel. Presented microstructure consists MC type carbide particles in a fine tempered martensite structure, what was confirmed by X-ray diffraction measurements.

a)

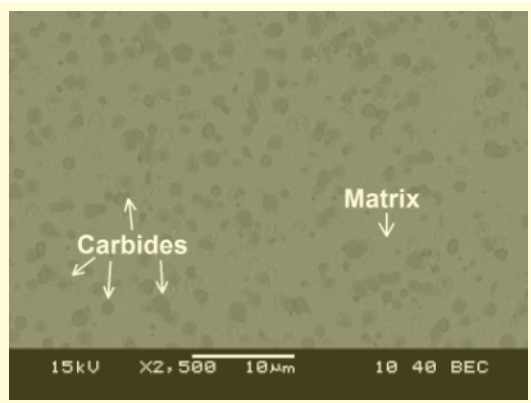

b)

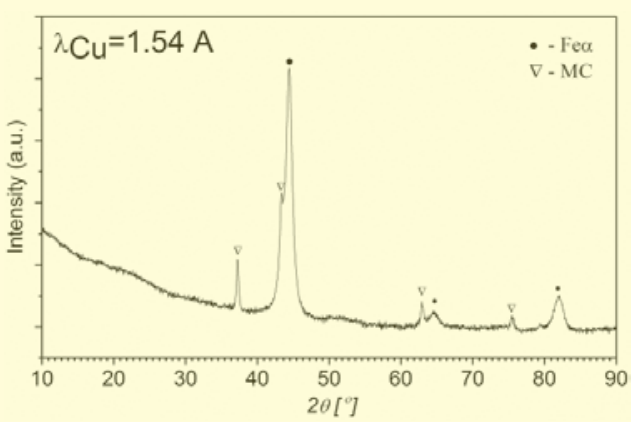

Fig. 3. SEM image (a) and XRD pattern (b) of Vanadis 8 tool steel

Topography with material ratio of the profile and selected surface roughness parameters after applied mechanical processes are given in Fig. 4. Obtained values of Sa parameter were lower than $0.1 \mu \mathrm{m}$, respectively $0.02 \mu \mathrm{m}$ and $0.08 \mu \mathrm{m}$ after $\mathrm{G}$ and HT processes. The other parameters were also slightly higher in the case of HT process.

The comparison of cross-sectional microstructure for samples after applied processes is shown in Fig. 5. As can be seen, G and HT machining do not cause substantial changes in the microstructure of their SLs. Except for slight edge irregularities in the first case, SLs of these samples are similar.

Table II presents results of residual stresses (measured according to the scheme shown in Fig. 2) after two different mechanical finishing processes. The results indicate an increase in the absolute values of the stress level, which range from $21 \%$ to $32 \%$, depending on the measurement direction defined by the angle $\varphi$. Higher values of compressive stresses were found for the $G$ operation. These results might be related to the penetration depth; that depth for copper radiation is about $6 \div 8 \mu \mathrm{m}$.

We now consider dynamic friction results shown in Fig. 6a. After $G$ operation the dynamic friction increases in the first stage reaching a value about 0.8 . Almost for the whole time of the test some fluctuations are visible. Whereas for the HT machining we observe a significant reduction of the friction relative to the $G$ process, amounting to about $30 \%$. In this case we also see a similar fluctuations during the test.

Another important factor illustrating differences in wear resistance of applied SL processes on Vanadis 8 tool steel is the wear rate; the respective values are presented in Fig. 6b. Thus, for samples after modification by the $\mathrm{G}$ treatment the average value of wear rate $=3.4$ has been 


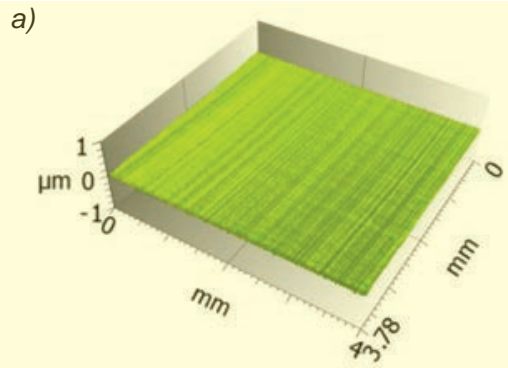

$S a=0.02 \mu \mathrm{m}$
$S z=0.25 \mu \mathrm{m}$
$S p=0.14 \mu \mathrm{m}$
$S v=0.11 \mu \mathrm{m}$

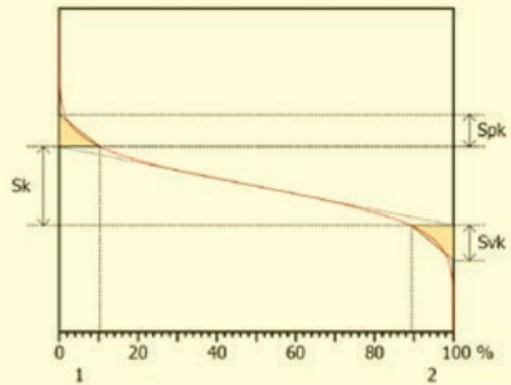

b)
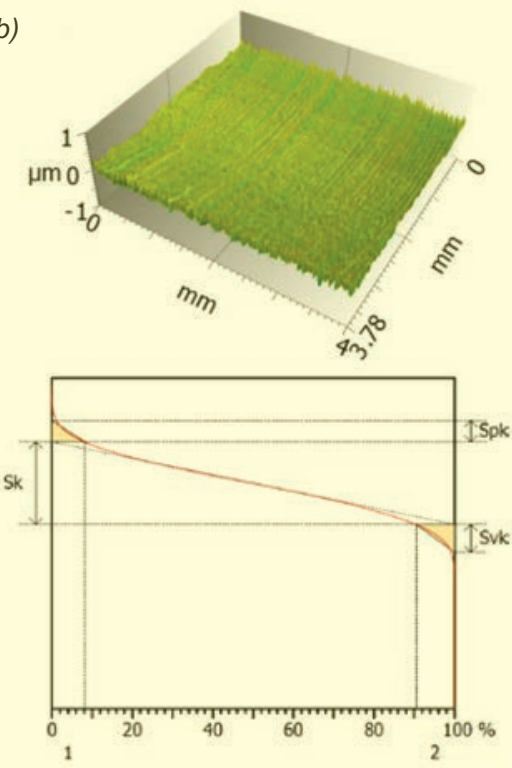

$\mathrm{Sa}=0.08 \mu \mathrm{m}$

$S z=1.14 \mu \mathrm{m}$

$S p=0.36 \mu \mathrm{m}$

$S v=0.77 \mu \mathrm{m}$

$S m r=50.9 \mu \mathrm{m}$

$S k=0.28 \mu \mathrm{m}$

Spk $=0.07 \mu \mathrm{m}$

$S v k=0.10 \mu \mathrm{m}$

Fig. 4. Topography with material ratio of the profile and surface roughness parameters of Vanadis 8 tool steel after: a) G, b) HT
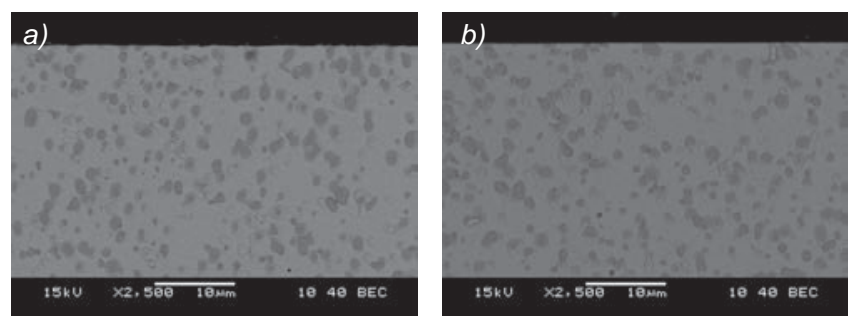

Fig. 5. Cross-sectional SEM micrographs of studied steel after: a) G, b) $\mathrm{HT}$

TABLE II. Results of stress measurements after selected mechanical SL treatment for Vanadis 8 steel

\begin{tabular}{|c|c|c|}
\hline \multirow{2}{*}{$\begin{array}{c}\text { Direction specified } \\
\text { by angle } \varphi\end{array}$} & \multicolumn{2}{|c|}{ Type of SL treatment } \\
\cline { 2 - 3 } & $\mathrm{G}$ & HT \\
\hline $0^{\circ}$ & $-1515.7 \pm 116$ & $-1192.9 \pm 217$ \\
\hline $90^{\circ}$ & $-806 \pm 116$ & $-549.5 \pm 228$ \\
\hline
\end{tabular}

achieved. Much lower values for surface after HT was obtained. For this machining operation the average value of wear was 2.2. In other words, the increase of wear resistance in this case reaches $40 \%$. a)

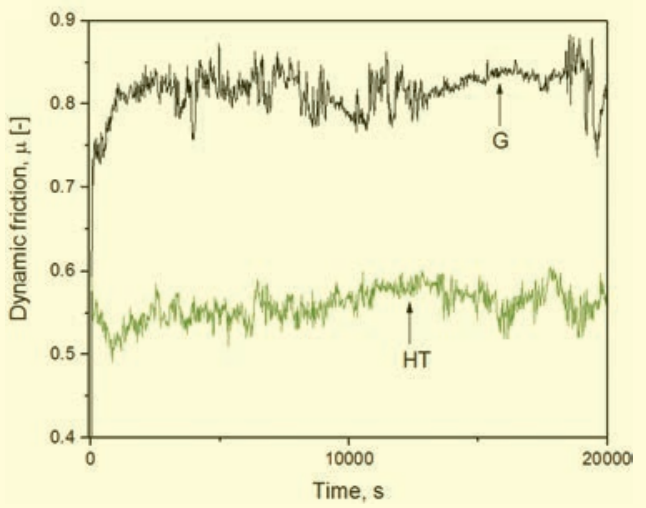

b)

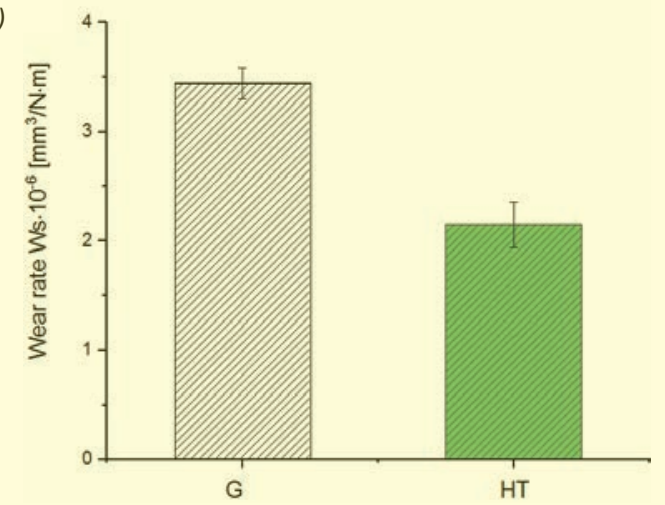

Rys. 6. Dynamic frictions (a) and wear rates $(b)$ obtained in pin-on-disc tests of Vanadis 8 steel after $\mathrm{G}$ and HT

\section{A survey of results}

Within this work, selected properties of hardened to $64 \pm 1 \mathrm{HRC}$ high-alloyed P/M Vanadis 8 tool steel were determined. Some conclusions can be summarized as follows:

- Microstructure after heat treatment, contains only one MC type carbide particles in a fine tempered martensite matrix.

- Machining by means of G or HT processes allows to form the SL with approximate surface roughness parameters (eg. Sa, Smr).

- Lower dynamic friction (about 30\%) and higher wear resistance (about $40 \%$ ) were achieved for surfaces after HT in comparison to $\mathrm{G}$.

This report is a part of a project supported by the LIDER/13/0075/L-7/15/NCBR/2016 entitled "Development of an innovative technology of obtaining functional properties of cold working tools" funded by the National Center for Research and Development of Poland, Warsaw.

\section{REFERENCES}

1. Hutchings I., Shipway P. "Tribology: friction and wear of engineering materials". Oxford - Cambridge MA: Butterworth - Heinemann 2017.

2. Brostow W., Hagg Lobland H.E. "Materials: Introduction and Applications". New York: John Wiley \& Sons, 2017.

3. Altan T., Ngaile G., Shen G. "Cold and Hot Forging: Fundamentals and Applications". Metal Parks, OH: ASM International, 2005.

4. Żak K., Grzesik W., Prażmowski M. "Investigation of sequential cryogenic hard turning and ball burnishing processes". Metalurgija. 53, 4 (2014): p. 521-525.

5. Toboła D., Brostow W., Czechowski K., Rusek P., Wronska I. "Structure and properties of burnished and nitrided AISI D2 tool steel". Materials Science Medžiagotyra. 21 (2015): s. 511-516.

6. Toboła D., Brostow W., Czechowski K., Rusek P. "Improvement of wear resistance of some cold working tool steels". Wear. 382-383 (2017): s. 29-39. 